Jurnal Akuntansi dan Investasi, Vol. 17 No. 2, Hlm: 158-175, Juli 2016

Artikel ini tersedia di website: http://journal.umy.ac.id/index.php/ai

DOI: 10.18196/jai.2016.0052.158-175

\title{
Pengaruh Partisipasi Anggaran terhadap Senjangan Anggaran dengan Asimetri Informasi, Penekanan Anggaran dan Komitmen Organisasional sebagai Variabel Pemoderasi
}

\author{
Muh. Irfan *; Budi Santoso; Lukman Effendi \\ Program Magister Akuntansi Universitas Mataram, Jl. Pemuda No. 35 Mataram, NTB, Indonesia
}

\section{ART I C LE IN FO}

Article history:

received 12 Mar 2016

revised 5 Agu 2016

accepted 20 Okt 2016

Keywords:

Budget Participation;

Information Asymmetry;

Budget Emphasis;

Organizational

Commitment;

Budgetary Slack

\begin{abstract}
A B S T RACT
This study aimed to examine the effect of budget participation toward budgetary slack with three moderating variables, namely: information asymmetry, budget emphasis and organizational commitment. Inconsistencies in previous studies on the effect of budget participation toward budgetary slack was become motivation in this study. Data were collected using a questionnaire distributed to the Local Government's Unit/SKPD Structural Officials of consisting of Echelon II, III and IV at the Regional Government of Dompu Regency. Respondents was selected by purposive sampling method in which officers involved in the budgeting process, of the 100 distributed questionnaires, all questionnaires were returned. The analysis method employs variant-based SEM using SmartPLS Version 2.0 M3. The research instrument has passed the test of validity and reliability. The results showed that budget participation has an influence on budgetary slack. This research may prove interaction with information asymmetry budget participation, budget emphasis has a significant negative effect, while the organizational commitment significantly influence budgetary slack. The implications of this study that the interaction of budget participation on information asymmetry and budget emphasis can reduce budgetary slack, otherwise committed organizations can improve budgetary slack.
\end{abstract}

(C) 2016 JAI. All rights reserved

\section{PENDAHULUAN}

Diberlakukannya otonomi daerah sesuai dengan amanat UU Nomor 32 Tahun 2004 yang diubah dengan UU Nomor 23 tahun 2014 tentang Pemerintahan Daerah, telah menyebabkan perubahan signifikan pada prosedur penyusunan Anggaran Pendapatan dan Belanja Daerah (APBD). Perubahan dimaksud mengacu pada meningkatnya keterlibatan berbagai pihak dalam penyusunan anggaran daerah tersebut, mulai dari kepala daerah hingga Satuan Kerja Perangkat Daerah (SKPD) yang berada di bawahnya. Hal ini dapat diartikan sebagai meningkatnya partisipasi pegawai dari tingkatan bawah dalam proses penyusunan anggaran. Fitriatsuri (2005) menyatakan perlunya dilakukan budgeting reform atau reformasi anggaran. Reformasi anggaran ini meliputi proses penyusunan, pengesahan, pelaksanaan dan pertanggungjawaban anggaran. Perbedaan lain yang mendasar dalam reformasi anggaran adalah sistem penyusunan anggaran yang bersifat bottom-up. Sistem yang melibatkan manajer atau pimpinan yang lebih rendah ini sering disebut dengan istilah partisipasi. Melalui reformasi anggaran ini diterapkan juga struktur organisasi yang terdesentralisasi sehingga pemerintah daerah mempunyai kekuasaan dan tanggungjawab dalam perencanaan, pelaksanaan dan pengawasan.

Reformasi penganggaran merupakan perubahan dari sistem anggaran tradisional (traditional budget system) ke sistem anggaran berbasis kinerja (performance budget system). Perubahan sistem penganggaran tersebut merupakan konsep New Public Management (NPM). Mahmudi (2003) menyatakan bahwa penerapan konsep New Public Management menyebabkan terjadinya perubahan manajemen sektor publik yang drastis dari sistem manajemen tradisional yang kaku, birokratis dan hierarkis menjadi model manajemen sektor publik yang fleksibel dan lebih mengakomodasi pasar. Suartana (2010) menyatakan bahwa sistem anggaran berbasis kinerja merupakan proses pembangunan yang efisien dan partisipatif dengan harapan dapat meningkatkan kinerja agen. Anggaran daerah disusun eksekutif sebagai agen dan disahkan oleh legislatif sebagai prinsipal. Namun, penilaian kinerja berdasarkan target anggaran akan mendorong agen untuk melakukan senjangan anggaran (budgetary slack) demi 
jenjang karir yang lebih baik di masa mendatang. Selain itu, senjangan anggaran juga sering terjadi pada tahap perencanaan dan persiapan anggaran daerah, karena penyusunan anggaran seringkali didominasi oleh kepentingan eksekutif dan legislatif, serta kurang mencerminkan kebutuhan masyarakat (Kartiwa, 2004).

Senjangan anggaran sendiri merupakan perbedaan antara anggaran yang direalisasikan dengan estimasi terbaik yang jujur diprediksikan (Suartana, 2010). Hasanah dan Suartana (2014) menyatakan bahwa senjangan anggaran diciptakan oleh manajer dengan menyembunyikan beberapa informasi pribadi dari atasan dan sengaja menggambarkan informasi yang hanya dapat menguntungkan diri sendiri melalui pengenalan slack (senjangan). Hal ini dapat berdampak buruk pada organisasi sektor publik yaitu terjadi kesalahan alokasi sumber daya dan bias dalam evaluasi kinerja agen terhadap unit pertanggungjawabannya. Menurut persepektif teori agensi (agency theory), adanya perbedaan informasi (asimetri informasi) antara bawahan (agent) dengan atasan (prinsipal) dalam proses partisipasi anggaran dikarenakan menggiring bawahan (agent) untuk memberikan informasi yang bias kepada atasanya (prinsipal) mengenai potensi yang dimiliki oleh organisasi, dengan cara menciptakan senjangan anggaran, yakni anggaran pendapatan ditentukan lebih rendah dari yang seharusnya.

Berdasarkan teori agensi (agency theory) dan penelitian terdahulu diatas, penentuan target pendapatan (revenue) yang dicapai, memiliki kecenderungan dianggarkan lebih rendah dari kemampuan maksimalnya (underestimate). Dengan target yang lebih rendah, yang tentunya target anggaran akan mudah dicapai, dapat dilihat pada pencapaian realisasi anggaran yang cendrung lebih besar dari anggarannya, sehingga persepsi akan kinerja meningkat pula, padahal realisasi tersebut merupakan potensi sesungguhnya dari pendapatan yang telah ditentukan lebih rendah dari estimasinya, yang merupakan indikasi dari senjangan anggaran pada pendapatan. Berbeda dengan pendapatan, belanja (expenditure) yang dicapai memiliki kecendrungan dianggarkan lebih tinggi dari yang seharusnya (over-estimate). Karena hal tersebut, maka realisasi belanja akan lebih rendah dari anggaran yang merupakan indikasi dari senjangan anggaran (budgetary slack) pada belanja. Dengan mengadopsi istilah 3E (ekonomis, efesiensi, efektifitas) pada anggaran berbasis kinerja, maka tidak tercapainya target anggaran tersebut merupakan efesiensi belanja, jika dikaitkan dengan anggaran tradisional atau basis kas, tidak tercapainya target anggaran tersebut merupakan sisa anggaran atau saldo kas yang merupakan penerimaan untuk tahun berikutnya yang disebut dengan istilah SiLPA (Sisa Perhitungan Lebih Anggaran Tahun Sebelumnya). Efesiensi tersebut dipersepsikan sebagai peningkatan kinerja yakni penghematan, padahal realisasi tersebut bukan merupakan yang sesungguhnya dari belanja yang telah ditentukan lebih tinggi dari estimasinya, yang merupakan indikasi dari senjangan anggaran pada belanja.

Anggaran Pemerintah Kabupaten Dompu memiliki perencanaan yang disesuaikan dengan harapan dan kebutuhan masyarakat melalui prioritas kebijakan belanja yang tidak akan terlepas dari Rencana Kerja Pemerintah Daerah (RKPD), sesuai dengan arah pembangunan daerah Pemerintah Kabupaten Dompu dapat tercermin melalui Laporan Realisasi Anggaran tahun 2014 di pos pendapatan dan belanja yang dirilis Dinas PPKAD Kabupaten Dompu. Berdasarkan Tabel 1, dapat dilihat bahwa fenomena bahwa perkembangan APBD Pemerintah Kabupaten Dompu Tahun anggaran tahun 2014, angka realisasi pendapatan untuk beberapa item pendapatan, jika dibandingkan anggaran dan realisasinya, terdapat beberapa item realisasi pendapatan lebih tinggi dengan anggaran yang telah ditetapkan. Kondisi ini memproyeksikan kearah senjangan anggaran (budgetary slack) dimana realisasi pendapatan selalu lebih tinggi dari anggaran pendapatan daerah.

Sedangkan pada Tabel 2 ditunjukkan angka realisasi belanja tidak mencapai $100 \%$, artinya anggaran belanja tidak diserap secara maksimal. Kondisi ini memproyeksikan kearah senjangan anggaran dimana realisasi belanja selalu lebih rendah dari anggaran belanja daerah. Walaupun anggaran Pemerintah Kabupaten Dompu dari tahun ketahun mengalami surplus tetapi pengestimasian, khususnya belanja dan pendapatan, cenderung terjadi slack (senjangan). Suartana (2010) menyatakan senjangan anggaran terjadi karena penentuan pendapatan yang terlalu rendah dan biaya yang terlalu tinggi.

Tabel 1. Komposisi Pendapatan Pemerintah Kabupaten Dompu Tahun 2014 (dalam rupiah) TAHUN 2014

\begin{tabular}{lccc} 
Uraian Pendapatan & Anggaran & Realisasi & \% \\
\hline Penpatan Asli Daerah & 71.373 .940 .344 & 75.370 .940 .344 & 105 \\
Pendapatan Transfer & 714.014 .076 .360 & 713.417 .226 .120 & 99 \\
Lain-lainya yang sah & 10.918 .827 .500 & 11.794 .299 .900 & 108 \\
\hline
\end{tabular}

Sumber: Dinas PPKAD Pemerintah Kabupten Dompu 
Tabel 2. Komposisi Belanja Pemerintah Kabupaten Dompu Tahun 2014 (dalam rupiah)

\begin{tabular}{lrrr}
\hline \multirow{2}{*}{ Uraian Belanja } & \multicolumn{2}{c}{ TAHUN 2014 } & \\
& Anggaran & Realisasi & \% \\
\hline Belanja Operasi & 649.497 .724 .236 & 606.209 .803 .509 & 93 \\
Pendapatan Transfer & 128.296 .026 .656 & 120.607 .395 .775 & 94 \\
Lain-lainya yang sah & 1.260 .756 .739 & 398.943 .000 & 31 \\
\hline
\end{tabular}

Sumber: Dinas PPKAD Pemerintah Kabupten Dompu

Beberapa penelitian telah dilakukan mengenai faktor-faktor yang dapat mengarah pada kecenderungan menciptakan senjangan anggaran (slack budgeting). Salah satu yang dianggap memiliki kecenderungan terjadinya slack adalah Pertisipasi Anggaran. Partisipasi pengganggaran adalah proses yang menggambarkan individu-individu terlibat dalam penyusunan anggaran dan mempunyai pengaruh terhadap target anggaran dan perlunya penghargaan atas pencapaian target anggaran tersebut (Falikhatun, 2007). Proses partisipasi anggaran terbilang efektif karena terjadi pertukaran informasi yang efektif sehingga besaran anggaran yang disetujui merupakan hasil dari keahlian dan pengetahuan pribadi dari pembuat anggaran yang dekat dengan lingkungan operasi (Govindarajan dan Anthony, 2007).

Menurut beberapa penelitian, partisipasi anggaran dinilai dapat memicu perilaku negatif yang dapat timbul dari keterlibatan bawahan (agent) dalam penyusunan anggaran, yaitu dengan cara menciptakan senjangan anggaran (Lau dan Eggleton, 2003; Veronika dan Komang, 2009; Afiani, 2010). Namun demikian, menurut Tjahjanti (2004), Sujana (2010), Dunk (1993), Supanto (2010), partisipasi yang tinggi dalam penyusunan anggaran juga dapat mengurangi terjadinya budget slack. Dari berbagai hasil penelitian yang menunjukkan adanya ketidak konsistenan antara penelitian yang satu dengan yang lainnya, maka diduga ada variabel lain mempengaruhi hubungan antara partisipasi dalam penyusunan anggaran dengan kemungkinan timbulnya slack anggaran.

Govindarajan (1986) menyatakan bahwa perbedaan hasil penelitian tersebut dapat diselesaikan melalui pendekatan kontinjensi (contingency approach). Hal ini dilakukan dengan memasukkan variabel lain yang mungkin mempengaruhi hubungan partisipasi dengan senjangan anggaran (budgetary slack). Dalam penelitian ini variabel yang diajukan adalah variabel asimetri informasi, penekanan anggaran dan komitmen organisasional. Mengacu pada Fitri (2004), dijelaskan bahwa senjangan terjadi disebabkan karena terdapat asimetri informasi antara manajer (bawahan) dengan atasan dalam suatu organisasi. Hubungan keagenan dalam konteks pemerintah daerah antara atasan dan bawahan, dimana bawahan melakukan proses perencanaan, pelaksanaan serta pelaporan atas anggaran daerah dengan membentuk Tim Anggaran
Pemerintah Daerah (TAPD), sedangkan atasan berperan dalam melaksanakan pengawasan. Menurut teori ini, hubungan antara bawahan dan atasan pada dasarnya sering berseberangan karena adanya kepentingan masing-masing pihak yang berbeda. Sehingga dalam partisipasi penganggaran, bawahan dapat menyembunyikan sebagian dari informasi pribadi mereka, yang dapat menyebabkan senjangan anggaran (budgetary slack).

Berdasarkan penjelasan diatas maka yang menjadi salah satu faktor yang diduga mempengaruhi hubungan partisipasi anggaran terhadap senjangan anggaran (budgetary slack) adalah asimetri informasi yaitu perbedaan informasi yang dimiliki agen dan prinsipal, sehingga prinsipal tidak mampu memonitor kemampuan agen yang sesungguhnya (Brahmayanti dan Sholihin, 2006). Asimetri informasi merupakan suatu kondisi apabila prinsipal tidak mempunyai informasi yang cukup mengenai kinerja agen baik itu dalam kinerja aktual, motivasi dan tujuan, sehingga atasan tidak dapat menentukan kontribusi bawahan terhadap hasil aktual perusahaan atau organisasi (Govindaradjan dan Anthony, 2007). Dunk (1993) menyatakan bahwa kinerja agen dinilai berdasarkan tercapai atau tidaknya target anggaran, maka agen termotivasi untuk tidak memberikan seluruh informasi yang dimilikinya pada saat perencanaan anggaran. Senjangan anggaran akan menjadi lebih besar dalam kondisi asimetri informasi karena asimetri informasi mendorong bawahan atau pelaksana anggaran membuat senjangan anggaran (Suartana, 2010). Hasil penelitian Young (1985), Utomo (2006), Djasuli dan Fadilah (2011) menyatakan bahwa interaksi partisipasi anggaran dan asimetri informasi berpengaruh positif dan signifikan pada senjangan anggaran. Berbeda dengan hasil Falikhatun (2007) yang menyatakan bahwa asimetri informasi tidak mampu memperkuat pengaruh penganggaran partisipatif pada senjangan anggaran.

Variabel lain yang diduga mempengaruhi hubungan antara partisipasi anggaran terhadap senjangan anggaran adalah penekanan anggaran, yaitu perusahaan menjadikan anggaran menjadi satu faktor yang paling dominan dalam pengukuran kinerja bawahan (Veronica dan Krisnadewi, 2008). Rani (2015) menjelaskan bahwa penekanan anggaran merupakan desakan dari atasan pada bawahan untuk melak- 
sanakan anggaran yang telah dibuat dengan baik, yang berupa sanksi jika kurang dari target anggaran dan kompensasi jika mampu melebihi target anggaran. Hasil Penelitian Afiani (2010), Chalos dan Poon (2000), Purgianto (2009) yang menunjukkan hasil siginifikan antara pengaruh penekanan anggaran terhadap senjangan anggaran. Berbeda dengan penelitian yang dilakukan Dunk (1993) menemukan bahwa penekanan anggaran yang tinggi maka senjangan anggaran rendah.

Faktor lain yang diduga dapat mempengaruhi hubungan partisipasi anggaran terhadap senjangan anggaran adalah Komitmen organisasional. Komitmen organisasional ditunjukkan dalam sikap penerimaan, keyakinan yang kuat terhadap nilai-nilai dan tujuan sebuah organisasi serta adanya dorongan yang kuat untuk mempertahankan keanggotaan dalam organisasi demi tercapai tujuan organisasi (Robbin, 2008). Hasil penelitian Ikhsan dan Ane (2007) menyatakan bahwa komitmen organisasional mampu memoderasi pengaruh anggaran partisipatif pada senajngan anggaran. Sementara dalam penelitian Desmiyati (2009) menyatakan bahwa interaksi anggaran partisipatif dan komitmen organisasional berpengaruh negatif dan tidak signifikan pada senjangan anggaran. Hal serupa dengan penelitian yang dilakukan Minan (2005) menyatakan bahwa komitmen organisasional tidak mempengaruhi hubungan antara anggaran partisipatif dengan senjangan anggaran.

Penelitian ini termotivasi oleh penelitian Supanto (2010) yang mengkaji pengaruh partisipasi anggaran terhadap senjangan anggaran dengan asimetri informasi, motivasi dan budaya organisasi sebagai variabel moderasi. Perbedaan penelitian ini dengan penelitian-penelitian sebelumnya terletak pada pemilihan variabel moderasi yang digunakan yakni mengganti budaya organisasi dalam penelitian Supanto (2010), tidak mampu memoderasi hubungan partisipasi anggaran terhadap senjangan anggaran dengan variabel penekanan anggaran dan komitmen organisasional serta waktu penelitian, dan teknik analisis data dengan Partial Least Square (PLS). Selain itu, penelitian ini menganggkat realita fenomena senjangan anggaran yang terjadi di Pemerintah Daerah Kabupaten Dompu.

Secara teoritis, hasil penelitian ini diharapkan dapat menambah literatur mengenai akuntansi sektor publik, terutama berkaitan dengan anggaran. Kepala daerah sebagai principal yang menjalankan fungsi pengawasan, serta mendelegasikan wewenang kepada kepala SKPD sebagai agent yang menjalan fungsi perencanaan, pelaksanaan dan pertanggungjawaban agar bekerjasama sehingga anggaran yang disusun merupakan partisipasi dari kepala daerah (principal) dan kepala SKPD (agent) sebagai wujud adopsi teori keagenan sektor publik. Selain itu, penelitian ini diharapkan dapat mendukung teori kontinjensi.

Terdapat ketidak konsistenan penelitianpenelitian terdahulu mengenai hubungan partisipasi anggaran terhadap senjangan anggaran, hal ini menunjukkan ada variabel lain yang mempengaruhi hubungan partisipasi anggaran dengan kemungkinan menimbulkan senjangan anggaran yang bersifat situasional yang dikenal dengan istilah variabel kontinjensi. Jika hasil penelitian ini menunjukkan variabel bebas (partisipasi anggaran) berpengaruh terhadap senjangan anggaran dengan asimetri informasi, penekanan anggaran dan komitmen organisasional sebagai variabel kontinjensi yang memoderasi pengaruh tersebut, maka hal tersebut akan memperkuat teori kontinjensi. Secara praktis, hasil penelitian ini dapat memberikan informasi kepada Pemerintah Daerah Kabupaten Dompu dan dapat dijadikan bahan pertimbangan mengenai hal-hal yang mesti dilakukan agar dalam menentukan dan menciptakan anggaran yang efektif dan efesien.

\section{TINJAUAN LITERATUR DAN PERUMUSAN HIPOTESIS}

\section{Teori Keagenan}

Inti dari teori keagenan adalah kontrak kerja yang didesain dengan tepat untuk menyelaraskan kepentingan antara prinsipal dengan agen (Supanto, 2010). Praktik senjangan anggaran mengandung pengertian dari teori keagenan, yaitu adanya konflik kepentingan antara agen (manajemen) dengan principal. Teori keagenan yang dijelaskan oleh Anthony dan Govindarajan (2007) merupakan suatu fenomena yang terjadi apabila atasan mendelegasikan wewenang kepada bawahan untuk melakukan suatu otoritas atau tugas dalam membuat keputusan. Hubungan keagenan dalam konteks pemerintah daerah antara atasan dan bawahan, dimana bawahan melakukan proses perencanaan, pelaksanaan serta pelaporan atas anggaran daerah dengan membentuk Tim Anggaran Pemerintah Daerah (TAPD), sedangkan atasan berperan dalam melaksanakan pengawasan. Menurut teori ini hubungan antara bawahan dan atasan pada dasarnya sering berseberangan karena adanya kepentingan masing-masing pihak yang berbeda.

\section{Teori Kontinjensi}

Pendekatan kontinjensi dalam perilaku organisasi adalah lingkungan yang berbeda menyebabkan adanya perilaku yang berbeda pula. Teori kontinjensi 
memotivasi adanya analisis situasi sebelum diambil tindakan dan menghilangkan perilaku yang biasa dilakukan berdasarkan asumsi tentang keprilakuan. Sehingga, teori kontinjensi dapat digunakan untuk semua pengetahuan yang mutakhir tentang organisasi dengan cara yang paling tepat, karena tindakan yang tepat bergantung pada variabel situasional (Davis dan Newstrom, 1985). Govindarajan (1986) hubungan antara partisipasi anggaran terhadap senjangan anggaran dapat diselesaikan melalui pendekatan kontinjensi (contingency approach), yakni dengan memasukkan variabel-variabel lain yang dapat memoderasi hubungan antara partisipasi anggaran dan senjangan anggaran. Dalam penelitian ini faktor kontinjensi (contingency approach) adalah asimetri informasi dan komitmen organisasional. Variabelvariabel tersebut yang akan memoderasi hubungan antara partisipasi anggaran dan senjangan anggaran.

\section{New Public Manajement (NPM)}

NPM berakar dari teori manajemen yang beranggapan bahwa praktik bisnis komersial dan manajemen sektor swasta adalah lebih baik dibandingkan dengan praktik dan manajemen sektor publik. Oleh karena itu, agar kinerja sektor publik dapat menjadi lebih baik, maka perlu untuk diadopsi beberapa praktik dan teknik manajemen yang diterapkan di sektor swasta ke dalam sektor publik (Mardiasmo, 2009). Konsep NPM juga memiliki keterkaitan dengan permasalahan manajemen kinerja sektor publik karena pengukuran kinerja menjadi salah satu prinsip NPM yang utama (Mahmudi, 2003). Penerapan konsep New Public Management ini menyebabkan terjadinya perubahan manajemen sektor publik yang drastis dari sistem manajemen tradisional yang kaku, birokratis dan hierarkis menjadi model manajemen sektor publik yang fleksibel dan lebih mengakomodasi pasar. Penerapan konsep NPM dapat dipandang sebagai bentuk modernisasi atau reformasi manajemen dan administrasi publik, depolitasi kekuasaan, atau desentralisasi wewenang atau desentralisasi wewenang yang mendorong demokrasi dalam pemerintahan (Mahmudi, 2003).

\section{Senjangan Anggaran}

Senjangan anggaran (budget slack) adalah perbedaan antara jumlah anggaran dan jumlah estimasi terbaik (Anthony dan Govindarajan, 2005). Senjangan anggaran adalah perbedaan antara anggaran yang dinyatakan dan estimasi anggaran terbaik yang secara jujur dapat diprediksi serta dibuat oleh penyusun anggaran dalam penganggaran. Variabel ini diukur dengan intrumen Dunk (1993). Masih Menurut Dunk (1993) manajer lebih cendrung menyusun anggaran yang lebih mudah untuk dicapai. Prilaku manajer melakukan senjangan anggaran dipengaruhi oleh kebijakan direktur yang menilai kinerja manajer berdasarkan pencapaian sasaran anggaran. Senjangan anggaran biasanya dilakukan dengan meninggikan biaya atau menurunkan pendapatan dari yang seharusnya, supaya anggaran mudah dicapai. Schiff dan Lewin (1970) mengindikasikan manajer dapat menciptakan senjangan anggaran dengan memperkecil pendapatan dan membebankan biaya menjadi lebih tinggi. Senjangan anggaran diciptakan oleh manajer yang dapat mengatur untuk menyembunyikan beberapa informasi pribadi dari atasan mereka dan sengaja menggambarkan informasi yang hanya dapat menguntungkan diri mereka sendiri melalui pengenalan senjangan (Hasanah dan Suartana, 2014).

Praktik senjangan anggaran mengandung pengertian dari teori keagenan, yaitu adanya konflik kepentingan antara agen (manajemen) dengan principal. Govindarajan dan Anthony (2007) menjelaskan bahwa konsep teori keagenan terjadi apabila atasan mendelegasikan wewenang kepada bawahan untuk melakukan suatu otoritas atau tugas dalam membuat keputusan. Hubungan keagenan dalam konteks pemerintah daerah antara atasan dan bawahan, dimana bawahan melakukan proses perencanaan, pelaksanaan serta pelaporan atas anggaran daerah sedangkan atasan berperan dalam melaksanakan pengawasan. Hasil Penelitian terdahulu yang dilakukan oleh Afiani (2010), Young (1985) dan Falikhatun (2007) menunjukkan bahwa partisipasi yang tinggi dalam proses penyusunan anggaran, dapat menimbulkan senjangan anggaran (budgetslack) yang tinggi pula. Namun hasil yang berlawanan ditunjukan dari penelitian Sujana (2010), Dunk (1993), Supanto (2010), Schift dan Lewin (1970) menunjukan bahwa partisipasi yang tinggi dalam penyusunan anggaran dapat mengurangi terjadinya senjangan anggaran (budgetslack). Hasil penelitian ini menunjukkan adanya ketidak konsistenan antara penelitian yang satu dengan yang lainnya, hal ini menunjukkan ada variabel lain mempengaruhi hubungan antara partisipasi dalam penyusunan anggaran dengan kemungkinan timbulnya slack anggaran.

Govindarajan (1986) menyatakan bahwa perbedaan hasil penelitian tersebut dapat diselesaikan melalui pendekatan kontinjensi (contingency approach). Hal ini dilakukan dengan memasukkan variabel-variabel lain yang dapat memoderasi hubungan antara partisipasi anggaran dan senjangan anggaran. Dalam penelitian ini faktor kontinjensi (contingency approach) adalah asimetri informasi, penekanan anggaran dan komitmen organisasional. Variabel- 
variabel tersebut yang akan memoderasi hubungan antara partisipasi anggaran dan senjangan anggaran.

Berdasarkan hasil penelitian terdahulu dan landasan teori yang telah diuraikan, peneliti mengidentifikan 1 (satu) variabel eksogen (independen) yakni Partisipasi Anggaran, 1 (satu) variabel endogen (dependen) yakni senjangan anggaran dan 3 (tiga) variabel moderasi yakni Asimetri Informasi, Penekanan Anggaran dan Komitmen organisasional yang diduga memoderasi pengaruh partsipasi anggaran terhadap Senjangan Anggaran sebagai variabel dependen. Adapun rerangka konseptual penelitian ini dapat dilihat pada Gambar 1.

\section{Pengaruh Partisipasi Anggaran terhadap Senjangan Anggaran}

Partisipasi anggaran adalah suatu proses dalam organisasi yang melibatkan individu-individu, yakni manajer dalam penyusunan anggaran untuk menentukan tujuan anggaran dan mempunyai target anggaran (Brownell, 1982). Proses penganggaran dapat dilakukan dengan metode top down, bottom up, dan partisipasif. Penyusunan anggaran merupakan salah satu sarana untuk berpartisipasi dalam pengambilan keputusan. Proses penyusunan anggaran merupakan bagian dari rangkaian proses anggaran yang disusun direktur (prinsipal) dan manajer (agen). Partisipasi anggaran diharapkan mampu mengakomodasikan anggaran yang diperlukan oleh unit dan rencana yang telah diprogramkan (Coryanata, 2006; Purwantini dan Suratno, 2007).

Partisipasi seluruh tingkat manajemen mulai dari proses penyusunan anggaran mulai dari proses penyusunan anggaran sampai dengan pelaksanaan anggaran dapat memberikan pengaruh positif dalam mencapai tujuan organisasi (Arifin W, 2012). Tingkat keterlibatan dan penagruh bawahan dalam proses penyusunan anggaran merupakan faktor utama yang membedakan anggaran partisipasif dan non partisipasif. Partisipasi dalam penyusunan anggaran memungkinkan manajer (sebagai bawahan) untuk melakukan negosiasi dengan atasan mengenai target anggaran yang dapat dicapai (Syam dan Djalil, 2006).

Terjadinya senjangan anggaran dalam partisipasi anggaran dikarenakan konstribusi bawahan (agent) yang tinggi dalam proses penyusunan anggaran. Perilaku ini dapat dijelaskan dengan teori keagenan, yang menjelaskan fenomena yang terjadi, ketika atasan (prinsipal) men delegasikan kepada bawahan (agent) untuk bertanggungjawab melakukan suatu tugas dan membuat keputusan. Agen diberikan wewenang untuk terlibat dalam proses partisiapsi anggaran. Keterlibatan bawahan (agent) dalam partisipasi anggaran akan memungkinkan manajer mempunyai informasi terkait organisasi. Senjangan anggaran timbul karena manajer yang ikut berpatisipasi dalam penyusunan anggaran memberikan informasi yang bias kepada atasan (prinsipal), padahal bawahan (agent) memiliki informasi yang dapat digunakan untuk membantu keakuratan anggaran organisasi. Bawahan (agent) menciptakan senjangan dengan mengestimasi pendapatan lebih rendah dan beban lebih tinggi agar target anggaran dapat dicapai. Sehingga partisipasi bawahan dalam proses penyusunan anggaran akan memicu ba bawahan (agent) melakukan tindakan yang ingin dicapai yaitu dengan menciptakan senjangan anggaran.

Pernyataan diatas didukung oleh Afiani (2010), Lowe dan Shaw (1968), Young (1985), menunjukkan

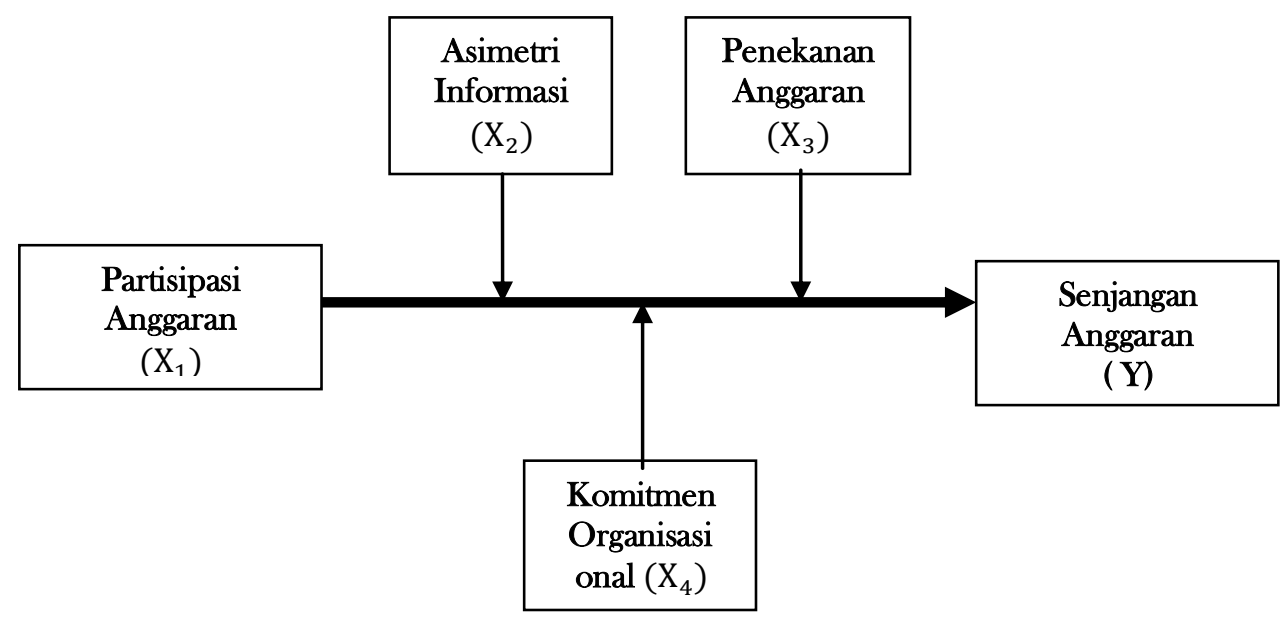

Gambar 1. Rerangka Konseptual Penelitian 
bahwa partisipasi yang tinggi dalam proses penyusunan anggaran, dapat menimbulkan senjangan anggaran (budget slack) yang tinggi pula. Namun hasil yang berlawanan ditunjukan dari penelitian Sujana (2010), Dunk (1993), Supanto (2010), Schift dan Lewin (1970) menunjukan bahwa partisipasi yang tinggi dalam penyusunan anggaran dapat mengurangi terjadinya budget slack. Hasil penelitian ini menunjukkan adanya ketidak konsistenan antara penelitian yang satu dengan yang lainnya, maka diusulkan hipotesis sebagai berikut:

$\mathrm{H}_{1}$ : Partisipasi anggaran berpengaruh terhadap senjangan anggaran.

\section{Kemampuan Asimetri Informasi Memoderasi Pengaruh Partisipasi Anggaran terhadap Senjangan Anggaran}

Rani (2015) menyatakan bahwa penentuan anggaran yang tepat memang tidak mudah dan akan menjadi masalah apabila bawahan mempunyai informasi yang lebih baik dibandingkan informasi yang dipunyai atasan. Perbedaan informasi yang dimiliki antara atasan dan bawahan inilah yang dinamakan informasi asimetri. Adanya informasi asimetri merupakan salah satu faktor yang menimbulkan perilaku negatif dalam hal ini adalah senjangan anggaran. Suartana (2010) menjelaskan bahwa konsep informasi asimetris yaitu atasan anggaran mungkin mempunyai pengetahuan dan wawasan yang lebih dari pada bawahan, ataupun sebaliknya. Bila kemungkinan yang pertama terjadi, akan muncul tuntutan atau motivasi yang lebih besar dari atasan kepada bawahan mengenai pencapaian target anggaran yang menurut bawahan terlalu tinggi. Namun, bila kemungkinan yang kedua terjadi, bawahan akan menyatakan target lebih rendah daripada yang dimungkinkan untuk dicapai.

Berdasarkan teori keagenan, manusia akan bertindak opportunistik yaitu mengutamakan kepentingan pribadi daripada kepentingan organisasi. Agen akan termotivasi untuk meningkatkan kompensasi di masa mendatang guna meningkatkan kinerjanya, sedangkan prinsipal termotivasi untuk meningkatkan utilitas dan profitabilitasnya. Prinsipal tidak dapat memonitor kegiatan agen setiap hari. Sebaliknya, agen mengetahui informasi penting mengenai kapasitas diri, lingkungan kerja dan organisasinya secara keseluruhan. Hal inilah yang menimbulkan asimetri informasi yaitu ketidakseimbangan informasi antara prinsipal dan agen.

Asimetri informasi yang terjadi antara prinsipal dan agen yang berpartisipasi dalam penganggaran dapat menimbulkan budgetary slack. Karena, kinerja yang dinilai dari tingkat pencapaian anggaran menjadi motivasi agen untuk melakukan asimetri informasi untuk memudahkan pencapaian anggaran. Peneltian ini, didukung oleh Young (1985), Utomo (2006), Djasuli dan Fadilah (2011) bahwa interaksi penganggaran partisipatif dan asimetri informasi berpengaruh positif dan signifikan pada budgetary slack. Menurut Falikhatun (2007), eksekutif sebagai agen cenderung melakukan budgetary slack, karena bertujuan untuk mengamankan posisinya di pemerintahan.

Berdasarkan tinjaun literatur dan hasil penelitian terdahulu, dapat disimpulkan bahwa asimetri informasi yaitu ketidakseimbangan informasi antara prinsipal dan agen dapat menimbulkan senjangan anggaran karena kinerja agen hanya diukur berdasarkan pencapaian anggaran yang memotivasi agen melakukan asimetri informasi. Sehingga dalam partisipasi anggaran agen dapat menyembunyikan sebagian informasi yang dapat menyebabkan senjangan anggaran (slack budgeting) dengan kata lain asimetri informasi mampu mempengaruhi hubungan partisipasi anggaran terhadap senjangan anggaran. Dengan demikian, peneliti mengajukan hipotesis sebagai berikut:

$\mathrm{H}_{2}$ : Asimetri Informasi memperkuat pengaruh partisipasi anggaran terhadap senjangan Anggaran.

\section{Kemampuan Penekanan Anggaran Memoderasi Pengaruh Partisipasi Anggaran terhadap Senjangan Anggaran}

Penekanan Anggaran merupakan desakan dari atasan pada bawahan untuk melaksanakan anggaran yangtelah dibuat dengan baik. Pengukuran kinerja berdasarkan anggaran yang telah disusun membuat bawahan akan berusaha memperoleh variance yang menguntungkan dengan menciptakan slack, antara lain dengan merendahkan penghasilan dan meninggikan biaya pada saat penyusunan anggaran (Rani, 2015). Menurut Gamal (2001) jika penilaian kinerja seseorang karyawan sangat ditentukan oleh anggaran yang telah disusun, maka bawahan cendrung melakukan senjangan anggaran. Bila bawahan diransang dengan adanya reward positif yang besar jika kerja melampaui anggaran dan bawahan akan dikenakan reward negatif bila kerjanya dibawah anggaran, maka bawahan akan cndrung melonggarkan anggaran dalam penyusunan supaya anggaran mudah dicapai atau dengan kata lain melakukan senjangan anggaran. Penekanan anggaran merupakan suatu kecendrungan yang terjadi untuk mencapai keberhasilan anggaran dengan cara termudah.

Penekanan anggaran merupakan desakan dari direktur pada manajer untuk melaksanakan anggaran yang telah dibuat sesuai dengan target. Penekanan anggaran dapat mempengaruhi senjangan anggaran. 
Hal ini dapat dijelaskan dengan teori keagenan yang menjelaskan fenomena pemberian wewenang dari atasan kepada bawahan untuk bertanggungjawab melakukan suatu tugas dan keputusan. Dalam teori keagenan direktur senantiasa mendesak agar manajer melakukan efesiensi dalam menjalankan aktivitas operasi dengan mengurangi beban dan meningkatkan pendapatan perusahaan. Target anggaran yang terlampau sulit mempengaruhi manajer untuk mengambil tindakan jangka pendek yang mudah dicapai. Penekanan anggaran yang diterapkan memicu terjadinya upaya manajer melakukan senjangan agar anggaran yang telah disusun di unit masing-masing mudah dicapai antara lain dengan cara melonggarkan anggaran. Manajer berusaha memperoleh perbedaan yang menguntungkan dengan cara menciptakan senjangan anggaran untuk mencapai target anggaran.

Hasil penelitian yang dilakukan oleh Afiani (2010), Chalos dan Poon (2000), Setiadi et al. (2013), Triana et al. (2012) dan Purgianto (2009) yang menunjukkan hasil siginifikan antara pengaruh penekanan anggaran (budget emphasis) terhadap senjangan anggaran. Namun, hasil penelitian yang dilakukan oleh Dunk (1993) dan Sujana (2010) yang menunjukkan penekanan anggaran (budget emphasis) tidak memiliki pengaruh yang signifikan terhadap senjangananggaran. Penekanan anggaran berpengaruh terhadap slack anggaran karena adanya pengukuran kinerja manajer berbasis anggaran dalam suatu organisasi.

Berdasarkan argument di atas, dapat disimpulkan bahwa target yang terlampau sulit akan mempengaruhi individu mengambil tindakan jangka pendek yang mudah dicapai yakni dengan cara melonggarkan anggaran sehingga memperoleh perbedaan yang menguntungkan dengan cara menciptakan senjangan anggaran untuk mencapai target anggaran. Dengan kata lain, penekanan anggaran mampu mempengaruhi hubungan partisipasi anggaran terhadap senjangan anggaran. Dengan demikian, peneliti mengajukan hipotesis sebagai berikut:

$\mathrm{H}_{3}$ : Penekanan anggaran memperkuat pengaruh partisipasi anggaran terhadap Senjangan Anggaran.

\section{Kemampuan Komitmen Organisasional Memoderasi Pengaruh Partisipasi Anggaran terhadap Senjangan Anggaran}

Menurut Robbin (2008) komitmen organisasional merupakan keyakinan dan dukungan yang kuat terhadap nilai dan sasaran yang ingin dicapai organisasi yang menggambarkan sejauh mana seorang karyawan memihak sebuah organisasi serta tujuantujuan dan keinginan untuk mempertahankan keanggotaan. Darlis (2002) menyatakan bahwa komit- men organisasional adalah dorongan dari dalam individu untuk berbuat sesuatu agar dapat menunjang keberhasilan organisasi sesuai dengan tujuan dan lebih mengutamakan kepentingan organisasi. Sementara Luthan (1998) mendefinisikan komitmen organisasional dalam tiga pengertian, yaitu: (1) keinginan kuat untuk tetap sebagai organisasi tertentu; (2) keinginan untuk berusaha keras sesuai keinginan organisasi; dan (3) keyakinan, penerimaan nilai dan tujuan organisasi.

Komitmen organisasional merupakan dimensi prilaku yang dapat digunakan untuk menilai kecenderungan karyawan untuk bertahan sebagai anggota organsasi, identifikasi dan keterlibatan seseorang yang relatif kuat terhadap organisasi, keinginan anggota organisasi untuk mempertahankan kenggotaannya dalam organisasi dan bersedia berusaha keras bagi pencapaian tujuan organisasi (Sopiah, 2008). Dalam proses penganggaran mengandung komitmen manajemen untuk mencapai target yang telah ditetapkan. Komitmen organisasional dapat berfungsi sebagai alat bantu psikologis dalam menjalankan organisasi tertentu. Kemudian, hasil proses penganggaran juga ditentukan oleh komitmen pelaksananya. Oleh karena itu komitmen karyawan atau sumber daya manusia dalam pelaksanaan proses penganggaran sangat diperlukan untuk mendapat hasil yang optimal.

Komitmen organisasional yang kuat di dalam diri individu akan menyebabkan individu berusaha kerasmencapai tujuan organisasi sesuai dengan tujuan dan kepentingan organisasiserta akan memiliki pandangan positif dan lebih berusaha berbuat yang terbaik demi kepentingan organisasi (Porter,1974). Hal ini dapat dijelaskan dengan teori keagenan yang menjelaskan fenomena pemberian wewenang dari atasan kepada bawahan untuk bertanggungjawab melakukan suatu tugas dan keputusan. Latuheru (2005) menyatakan bahwa naik atau turunnya senjangan anggaran tergantung pada apakah individu memilih untuk mengejar kepentingannya sendiri atau justru bekerja untuk kepentingan organisasi. dengan kata lain bahwa komitmen organisasional mampu mempengaruhi hubungan partsipasi anggaran terhadap senjangan anggaran. Sebaliknya, individu dengan komitmen rendah akan mementingkan dirinya atau kelompoknya. Dia tidak memiliki keinginan untuk menjadikan organisasi ke arah yang lebih baik, sehingga memungkinkan terjadinya senjangan anggaran apabila dia terlibat dalam penyusunan anggaran (Kartika, 2010). Hasil penelitian terdahulu yang dilakukan Ikhsan dan Ane (2007) menyatakan bahwa komitmen organisasional mampu memoderasi pengaruh anggaran partisipatif pada senjangan anggaran.

Berdasarkan tinjaun literatur dan hasil penelitian terdahulu, dapat disimpulkan bahwa proses 
partisipasi anggaran juga ditentukan oleh komitmen pelaksananya, ketika individu mengejar kepentingan pribadi yakni memiliki komitmen organisasional rendah, maka individu tersebut dalam partisipasi penganggaran akan berusaha melakukan senjangan anggaran agar kinerjanya terlihat baik,sehingga akan meningkatkan senjangan anggaran, dengan kata lain bahwa komitmen organisasional mampu mempengaruhi hubungan partsipasi anggaran terhadap senjangan anggaran. Dengan demikian, peneliti mengajukan hipotesis sebagai berikut:

$\mathrm{H}_{4}$ : Komitmen organisasional yang rendah semakin meningkatkan senjangan anggaran pada proses partisipasi anggaran.

\section{METODE PENELITIAN}

\section{Populasi dan Sampel Penelitian}

Populasi dalam penelitian ini yaitu seluruh aparat/pejabat struktural pada Eselon II, III, dan IV pada Pemerintah Kabupaten Dompu sebanyak 538 orang yang tersebar di 37 SKPD. Teknik pengambilan sampel dilakukan dengan metode purposive sampling, didasarkan pada pertimbangan bahwa sampel tersebut adalah aparat/pejabat teknis yang terlibat dalam penyusunan, pelaksanaan dan pelaporan anggaran di setiap SKPD, jumlah sampel yaitu 100 responden.

\section{Tabel 3. Instrumen Pengukuran Variabel}

\begin{tabular}{|c|c|c|c|}
\hline No & Variabel & Indikator & Sumber/Skala \\
\hline 1) & Senjangan Anggaran (Y) & $\begin{array}{l}\text { a. Jumlah anggaran pendapatan yang dibuat } \\
\text { lebih rendah dari seharusnya. } \\
\text { b. Jumlah anggaran belanja yang dibuat lebih } \\
\text { tinggi dari seharusnya disusun. }\end{array}$ & $\begin{array}{l}\text { Begum (2009)/Skala Likert } \\
\text { dengan skor } 1 \mathrm{~s} / \mathrm{d} 5\end{array}$ \\
\hline 2) & Partisipasi Anggaran $\left(\mathrm{X}_{1}\right)$ & $\begin{array}{l}\text { a. Kemampuan memberikan pendapat dalam } \\
\text { penyusunan anggaran. } \\
\text { b. Frekuensi memberikan pendapat/usulan } \\
\text { tentang anggaran kepada atasan } \\
\text { c. Frekuensi atasan meminta pendapat ketika } \\
\text { anggaran disusun } \\
\text { d. Konstribusi dalam penyusunan anggaran }\end{array}$ & $\begin{array}{l}\text { Supriyatno }(2010) / \text { Skala } \\
\text { Likert dengan skor } 1 \mathrm{~s} / \mathrm{d} 5\end{array}$ \\
\hline 3) & Asimetri Informasi $\left(\mathrm{X}_{2}\right)$ & $\begin{array}{ll}\text { a. Kecukupan informasi } \\
\text { b. Kualitas informasi } \\
\text { c. Kuantitas informasi } \\
\text { d. Pemahaman informasi }\end{array}$ & $\begin{array}{l}\text { Novita et al. (2015)/Skala } \\
\text { Likert dengan skor } 1 \mathrm{~s} / \mathrm{d} 5\end{array}$ \\
\hline 4) & Penekanan Anggaran $\left(\mathrm{X}_{3}\right)$ & $\begin{array}{l}\text { a. Anggaran sebagai fungsi pengawasan } \\
\text { b. Anggaran sebagai tolak ukur kinerja } \\
\text { c. Kemampuan dalam mencapai target } \\
\text { anggaran } \\
\text { d. Reward (penghargaan) ketika mencapai } \\
\text { target anggaran } \\
\text { e. Anggaran yang ditetapkan meningkatkan } \\
\text { kinerja. } \\
\end{array}$ & $\begin{array}{l}\text { Rani (2015)/ Skala Likert } \\
\text { dengan skor } 1 \mathrm{~s} / \mathrm{d} 5\end{array}$ \\
\hline 5) & Komitmen organisasional $\left(\mathrm{X}_{4}\right)$ & $\begin{array}{l}\text { a. Kesanggupan untuk bekerja diatas rata-rata } \\
\text { b. Kebanggaan terhadap organisasi tempat } \\
\text { bekerja } \\
\text { c. Kesediaan untuk mengerjakan semua } \\
\text { pekerjaan } \\
\text { d. Kesesuian nilai individu dengan nilai } \\
\text { organisasi } \\
\text { e. Kebanggaan menjadi bagian organisasi } \\
\text { f. Penangaruh organisasi dalam berprestasi } \\
\text { g. Kepuasan memilih organisasi tempat } \\
\text { h. Kekerja } \\
\text { i. Penilian pegawai terhadap organisasi }\end{array}$ & $\begin{array}{l}\text { Sumarno }(2005) / \text { Skala } \\
\text { Likert dengan skor } 1 \text { s/d } 5\end{array}$ \\
\hline
\end{tabular}

\section{Variabel Penelitian dan Pengukurannya}

Variabel dalam penelitian ini dibagi menjadi lima yaitu Variabel Eksogen adalah Partisipasi angga- ran, Variabel Endogen adalah senjangan annggaran, Variabel Moderasi adalah Asimetri Informasi, Penekanan Anggaran dan Komitmen organisasional. Pengukuran Variabel disajikan pada Tabel 3. 


\section{Analisis Data}

Metode analisis data yang digunakan dalam pengujian hubungan antar variabel penelitian ini adalah metode Partial Least Square (PLS). Analisis data meliputi uji validitas dan reliabilitas instrumen, evaluasi inner model dan pengujian hipotesis secara sraristik (Sofyani dan Akbar, 2013; 2015).

\section{HASIL DAN PEMBAHASAN}

\section{Evaluasi Model Pengukuran (Outer Model)}

Model pengukuran digunakan untuk menguji validitas konstruk dan reliabilitas dari instrumen penelitian, yakni angket kuesioner yang dibgikan kepada sampel penelitian. Uji validitas dalam penelitian ini yaitu convergent validity dan discriminant validity, sedangkan untuk uji reliabilitas yaitu composite reliability.

\section{Uji Validitas}

Pengujian validitas indikator konstruk dilakukan dengan convergent validity, dan discriminant validity. Convergent validity dari model pengukuran dengan refleksif indicator dinilai berdasarkan korelasi antara item score/component score dengan construct score yang dihitung dengan PLS (Ghozali, 2008:24). Hal senada juga disampaikan oleh Hartono (2011) uji validitas konvergen dalam PLS dengan indikator reflektif dinilai berdasarkan loading factor (korelasi antara skor item/skor komponen dengan skor konstruk) indikator-indikator yang mengukur konstruk tersebut. Menurut Chin (1995) dalam Jogiyanto, (2011) rule of thumb yang digunakan untuk validitas konvergen adalah Communality $>0,5$ dan Average Variance Extracted (AVE) > 0,5. Hasil analisis dapat dilihat pada Gambar 3.

Berdasarkan hasil analisis ditemukan masih terdapat variabel manifes/teramati/indikator yang memiliki nilai loading factor < 0,50, yaitu X1.3, X1.4, $\mathrm{X} 4.2, \mathrm{X} 4.3, \mathrm{X} 4.5, \mathrm{X} 4.7$ dan X4.8,maka indikatorindikator tersebut harus di drop dari model. Hal ini dapat dilihat pada Tabel 4. Setelah indikator-indikator tersebut didrop, selanjutnya dilakukan analisis kembali dengan menggunakan PLS terhadap model. Hasil dari analisis kembali ini dapat disimak pada Gambar 4.

Berdasarkan hasil analisis, ditemukan masih terdapat variabel manifes/teramati/indikator yang memiliki nilai loading factor $<0,50$, yaitu X2.3. Dari hasil tersebut maka indikator yang nilainya $<0,50$ harus di drop (dibuang) dari model. Hal ini dapat dilihat pada Tabel 5 .

Tabel 4. Hasil analisis Indikator loading factor $<0,50$

\begin{tabular}{ccc}
\hline Indikator & Loading factor $<0,50$ & Keterangan \\
\hline X1.3 & 0,475 & drop \\
X1.4 & 0,439 & drop \\
X4.2 & 0,276 & drop \\
X4.5 & 0,048 & drop \\
X4.7 & 0,348 & drop \\
X4.8 & 0,067 & drop \\
\hline
\end{tabular}

Tabel 5. Hasil analisis Indikator loading factor $<0,50$

\begin{tabular}{ccc} 
Indikator & Loading factor $<0,50$ & Keterangan \\
\hline $\mathrm{X} 2.3$ & 0,316 & drop \\
\hline
\end{tabular}

Setelah indikator-indikator tersebut didrop, selanjutnya dilakukan analisis kembali terhadap model. Berdasarkan hasil analisis, indikator-indikator memiliki nilai loading factor $>0,50$. Hasil analisis dapat dilihat pada Gambar 5 .

Model struktural awal pada Gambar 2 telah mengalami perubahan menjadi seperti Gambar 3. Selain melihat loading factor, rule of thumb yang digunakan untuk convergent validity adalah outer loading $>0,7$, Communality $>0,5$ dan average variance extracted (AVE) > 0,5, nilai AVE dan Communality ditunjukkan pada Tabel 6 .

Tabel 6. Nilai AVE dan Communality

\begin{tabular}{ccc}
\hline & AVE & Communnality \\
\hline X1 & 0,772025 & 0,772025 \\
$\mathrm{X} 1{ }^{*} \mathrm{X} 2$ & 0,763162 & 0,763162 \\
$\mathrm{X} 1{ }^{*} \mathrm{X} 3$ & 0,772335 & 0,772335 \\
$\mathrm{X} 1{ }^{*} \mathrm{X} 4$ & 0,739909 & 0,739909 \\
$\mathrm{X} 2$ & 0,561358 & 0,561358 \\
$\mathrm{X} 3$ & 0,615480 & 0,615480 \\
$\mathrm{X} 4$ & 0,513453 & 0,513453 \\
Y & 0,710114 & 0,710114 \\
\hline
\end{tabular}

Dari Tabel 6 dapat dilihat nilai AVE dan communality $>0,50$, sehingga memenuhi persyaratan rule of thumb yang digunakan untuk convergent validity. Discriminant validity dari model pengukuran dengan refleksif indikator dinilai berdasarkan cross loading pengukuran dengan konstruknya. Metode lain untuk menilai discriminant validity adalah membandingkan nilai square root of average variance extrated (AVE) setiap konstruk dengan korelasi antara konstruk dengan konstruk lainnya dalam model. Dalam penelitian ini metode yang dipakai adalah dengan melihat nilai cross loading. Berdasar- 


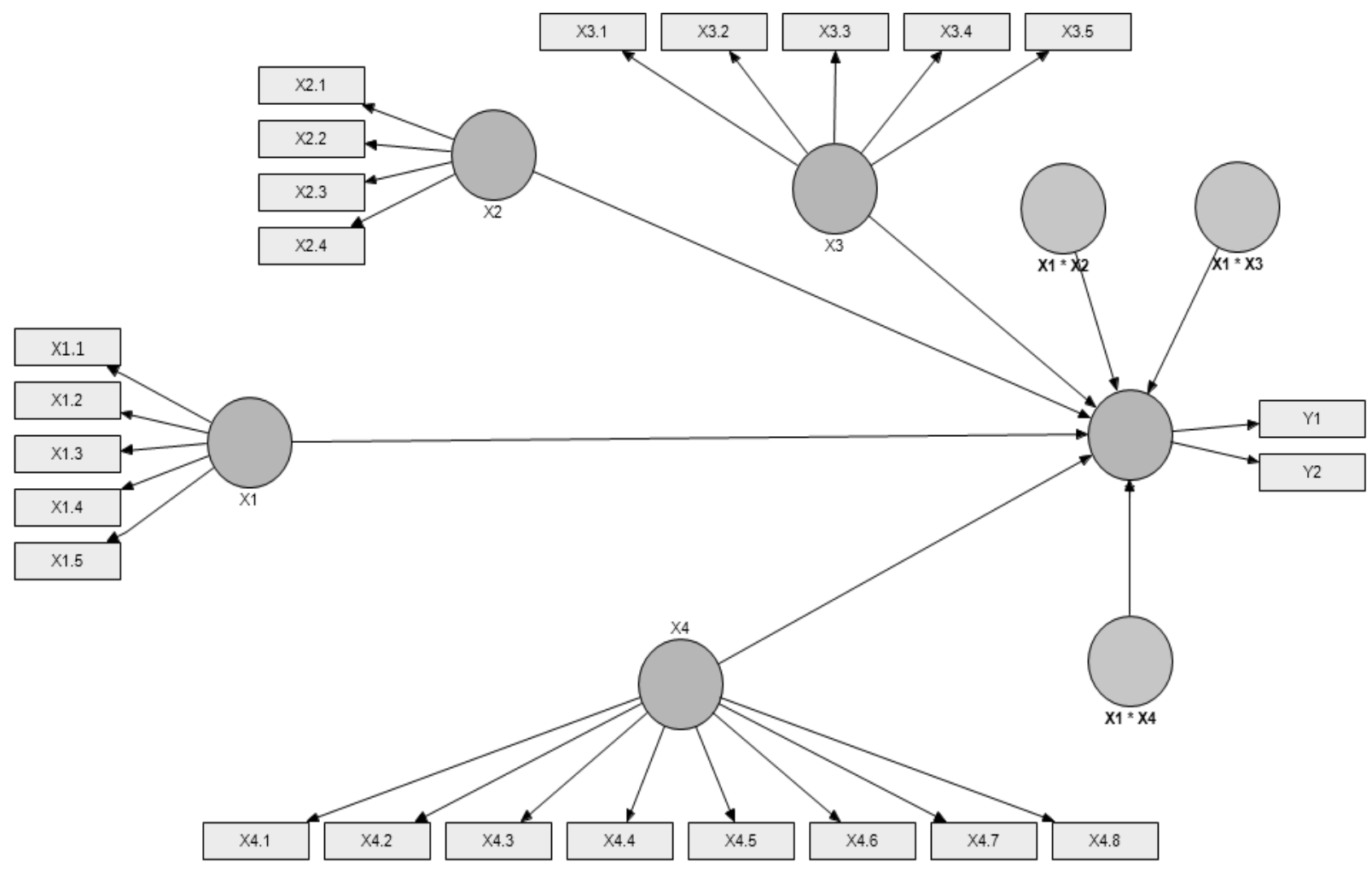

Gambar 2. Ilustrasi Model Struktural Awal

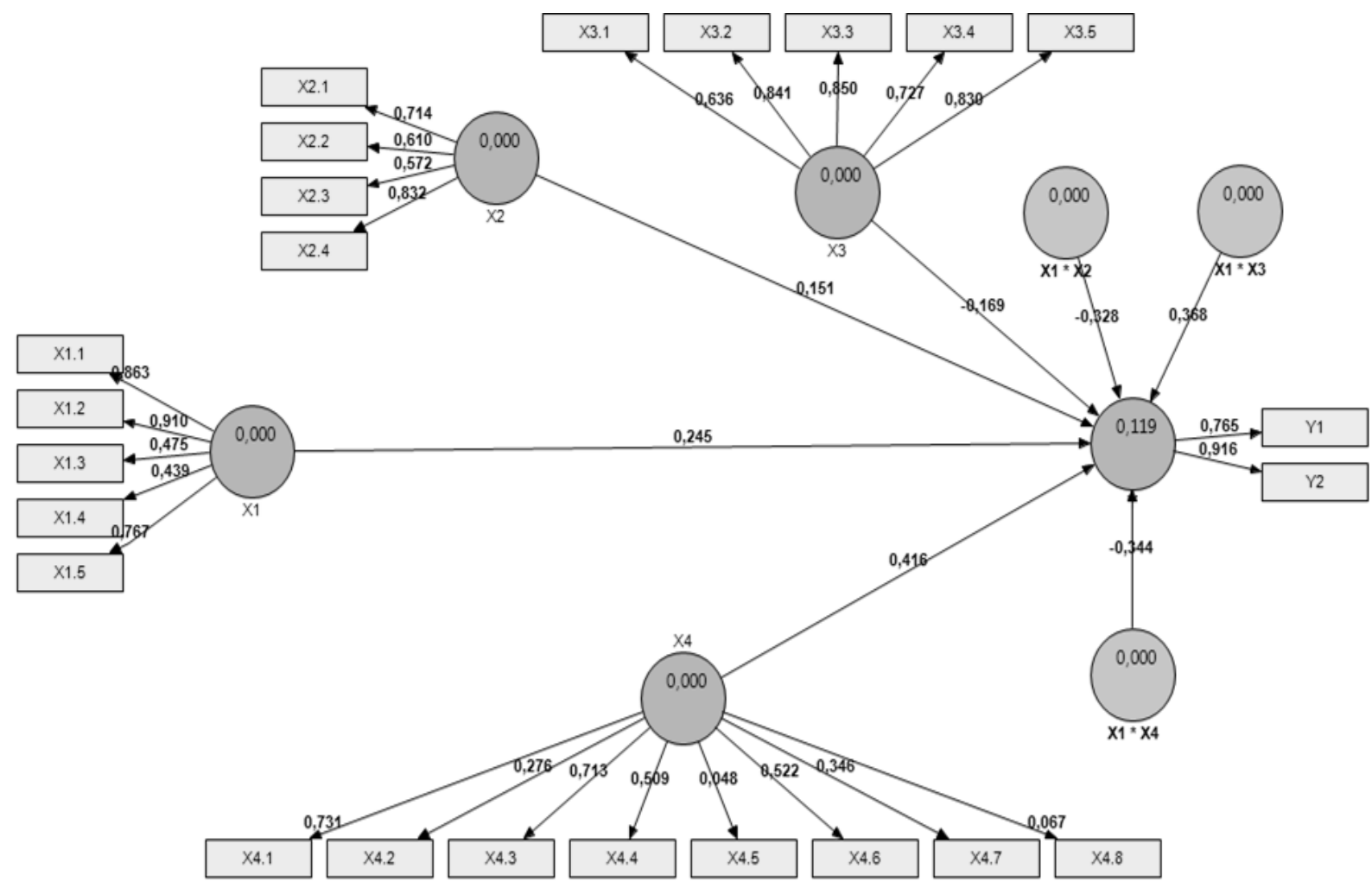

Gambar 3. Model Pengukuran (Outer Model) I 


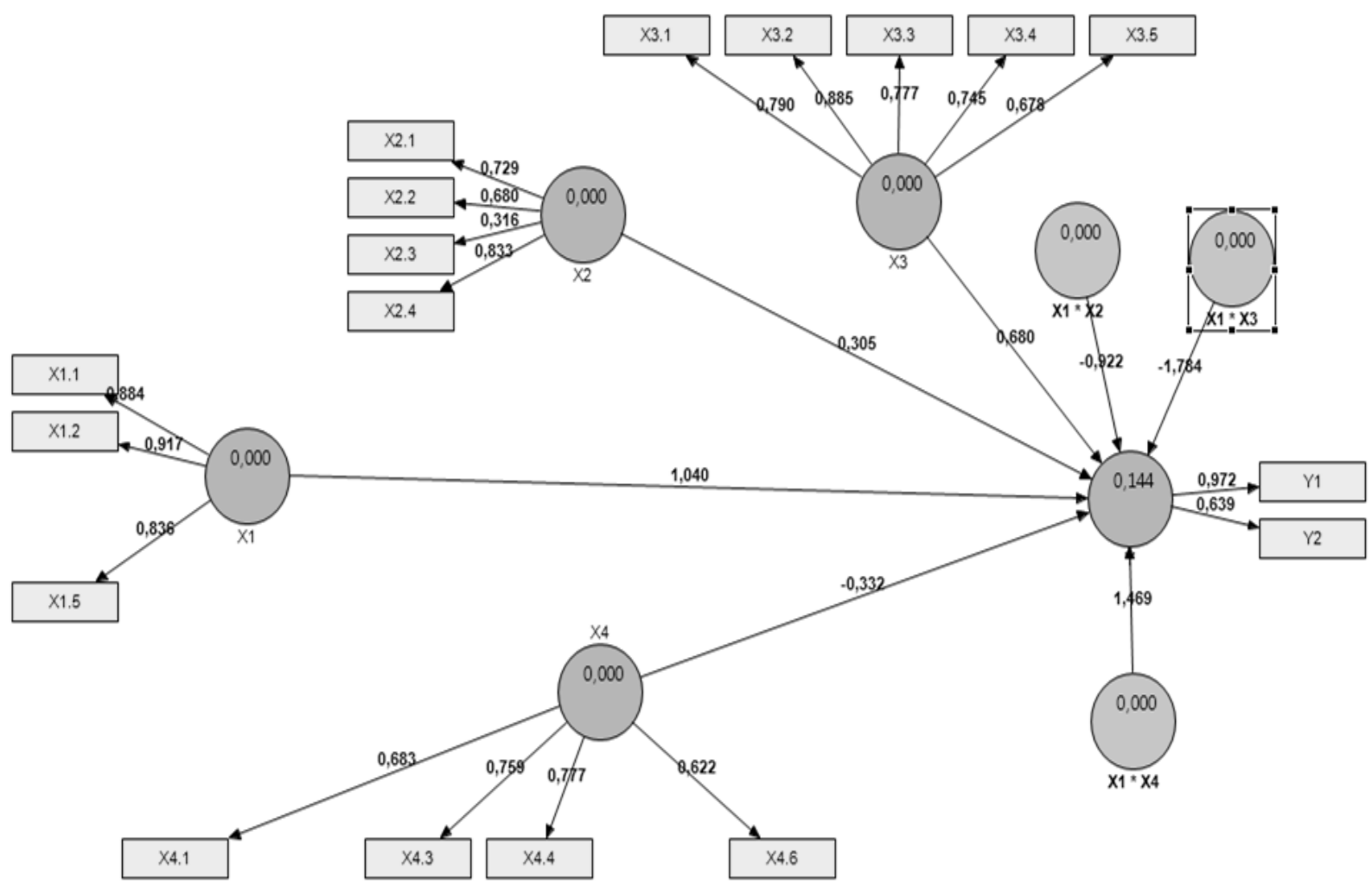

Gambar 4. Model Pengukuran (Outer Model) II

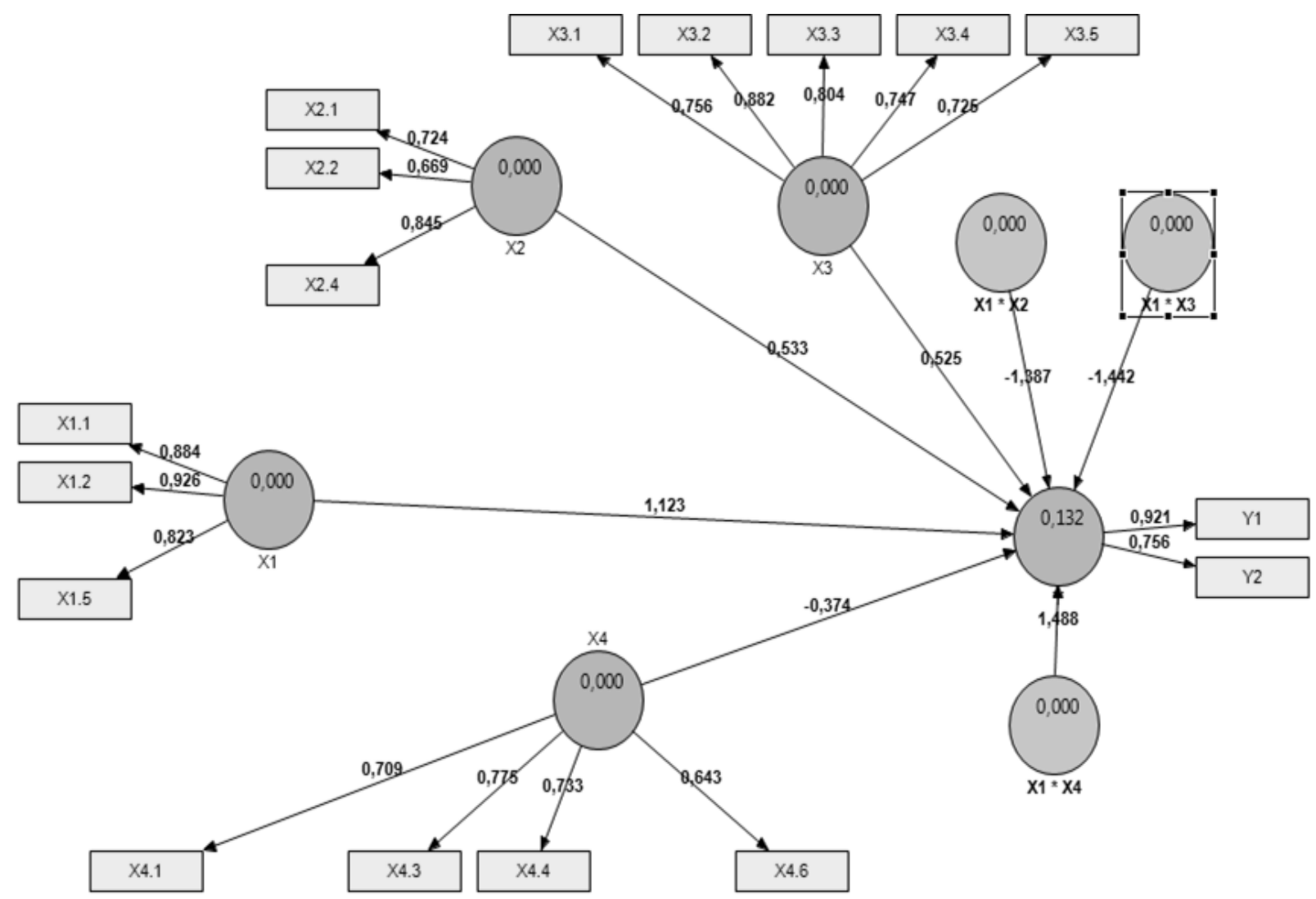

Gambar 5. Model Pengukuran (Outer Model) III 
kan nilai cross loading untuk semua konstruk > 0,60 sehingga memenuhi persyaratan discriminant validity.

\section{Uji Reliabilitas}

Uji reliabiltas pada model pengukuran (outer model) pada indikator reflektif dengan melihat nilai Composite Reliability. Indikator dinyatakan reliabel atau memiliki reliabilitas baik apabila nilai Composite Reliability > 0,70. Hasil perhitungan Composite Reliability dalam penelitian ini, ditampilkan pada Tabel 7 berikut:

Tabel 7. Nilai Composite Reliability

\begin{tabular}{cc}
\hline & Composite Reliability \\
\hline $\mathrm{X} 1$ & 0,910197 \\
$\mathrm{X} 1{ }^{*} \mathrm{X} 2$ & 0,966612 \\
$\mathrm{X} 1{ }^{*} \mathrm{X} 3$ & 0,980705 \\
$\mathrm{X} 1{ }^{*} \mathrm{X} 4$ & 0,971519 \\
$\mathrm{X} 2$ & 0,791768 \\
$\mathrm{X} 3$ & 0,888427 \\
$\mathrm{X} 4$ & 0,807783 \\
$\mathrm{Y}$ & 0,829124 \\
\hline
\end{tabular}

Tabel 7 di atas menunjukkan bahwa nilai composite reliability $>0,70$, sehingga dapat disimpulkan bahwa semua indikator konstruk adalah reliabel atau memenuhi uji reliabilitas.

\section{Evaluasi Inner Model}

Evaluasi inner model dilakukan dengan uji bootstrapping. Evaluasi model struktural (inner model) merupakan model struktural untuk memprediksi hubungan kausalitas antar variabel laten melalui uji bootstrapping, untuk memprediksi adanya hubungan kausalitas model structural (inner model) dievaluasi dengan menggunakan R-square untuk konstruk dependen, Stone-Geiser Q-square test untuk predictive relevance dan uji t serta signifikansi dari koefisien parameter jalur struktural. Dalam menilai model dengan PLS dengan melihat R-square untuk setiap variabel laten eksogen. Dari hasil analisis ditemukan nilai R-square untuk variabel laten endogen Y1 adalah 0,13740 yang berarti model ini mampu menjelaskan 13,74 \% perubahan pada variabel laten endogen Y1 dan sisanya sebesar 86,26 $\%$ dijelaskan oleh faktor lain diluar yang diteliti.

\section{Pengujian Hipotesis}

Setelah analisis model dilakukan, analisis selanjutnya adalah pengujian hipotesis, analisis ini dilakukan dengan membandingkan nilai T-table dengan nilai T-statistics yang dihasilkan dari proses bootstrapping dalam PLS. Hipotesis diterima (terdukung) jika nilai T-statistics lebih tinggi daripada nilai T-table $(1,65)$ dengan signifikansi level $10 \%$ (two tailed) (Ghozali, 2012:85). Hasil proses bootstrapping PLS dapat dilihat pada Gambar 6 dan Tabel 8.

\section{Pengujian Pengaruh Partisipasi Anggaran terhadap Senjangan Anggaran}

Analisis yang digunakan dalam penelitian ini adalah analisis PLS-SEM biasa disebut dengan Component Based SEM atau sering disebut juga dengan soft modeling untuk menentukan pengaruh variabel eksogen terhadap variabel endogen. Berdasarkan hasil analisis pada Tabel 8, hipotesis 1 yang menyatakan bahwa partisipasi anggaran berpengaruh signifikan terhadap senjangan anggaran. Hasil uji hipotesis menunjukkan path coeficient antara partisipasi anggaran dengan senjangan anggaran memiliki nilai T-statistics $(1,689012)>T$ table $(1,65)$ dengan signifikansi level 10\% (two tailed), menunjukkan bahwa partisipasi anggaran berpengaruh signifikan terhadap senjangan anggaran. Artinya hipotesis 1 diterima.

Hubungan keagenan antara Kepala Daerah (Bupati) dan Kepala Dinas/Kantor/Badan adalah Kepala Daerah (Bupati) berperan sebagai prinsipal dan Kepala Dinas/Kantor/Badan sebagai agen, dimana risiko ketidakpastian lingkungan dan penilaian kinerja menjadi motivasi kepala SKPD untuk melakukan budgetary slack. Agen termotivasi untuk mengembangkan karir ke jenjang yang lebih tinggi dan meningkatkan kompensasinya di masa mendatang. Senjangan anggaran (budgetari slack) yang

Tabel 8. Path Coefficients (Mean, STDEV, T-Values)

\begin{tabular}{lccccc}
\hline & $\begin{array}{c}\text { Original } \\
\text { Sample (O) }\end{array}$ & $\begin{array}{c}\text { Sampel } \\
\text { Mean (M) }\end{array}$ & $\begin{array}{c}\text { Standard Deviation } \\
\text { (STDEV) }\end{array}$ & $\begin{array}{c}\text { Standard Error } \\
\text { (STERR) }\end{array}$ & $\begin{array}{c}\text { T Statistics } \\
(|\mathbf{O} / \mathbf{S T E R R}|)\end{array}$ \\
\hline $\mathrm{X} 1$ - > Y & 1,122651 & 0,788910 & 0,664679 & 0,664679 & 1,689012 \\
$\mathrm{X} 1{ }^{*} \mathrm{X} 2$-> Y & $-1,386598$ & $-0,827653$ & 0,743916 & 0,743916 & 1,863918 \\
$\mathrm{X} 1{ }^{*} \mathrm{X} 3$-> Y & $-1,442018$ & $-0,697624$ & 0,766708 & 0,766708 & 1,880793 \\
X1 * X4 -> Y & 1,487704 & 0,604677 & 0,895833 & 0,895833 & 1,660693 \\
X2 & 0,532835 & 0,362965 & 0,310194 & 0,310194 & 1,717747 \\
X3 & 0,525465 & 0,196901 & 0,352782 & 0,352782 & 1,489491 \\
X4 & $-0,373976$ & $-0,033076$ & 0,367766 & 0,367766 & 1,016887 \\
\hline
\end{tabular}




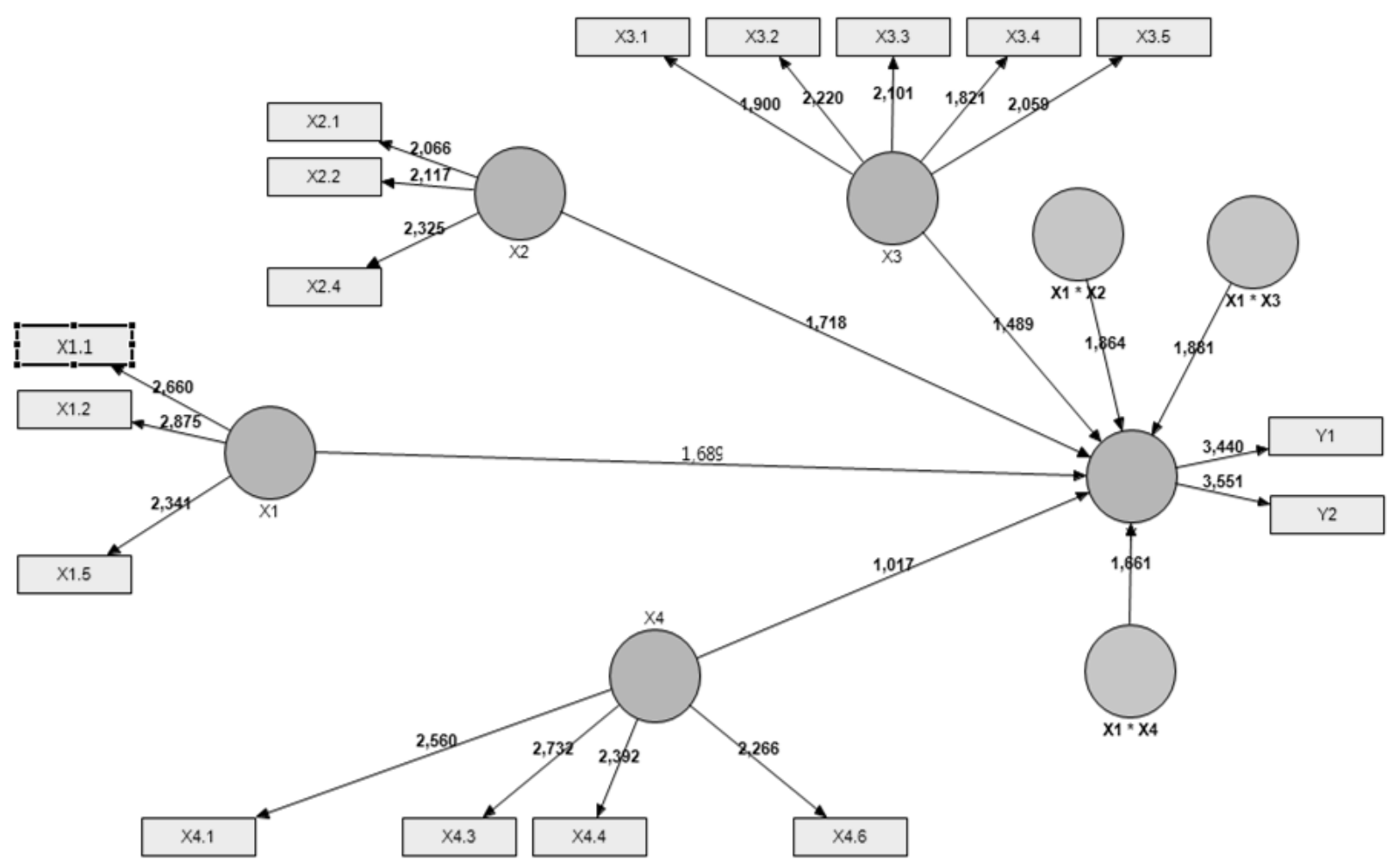

Gambar 6. Hasil Proses Bootstrapping

diciptakan oleh perangkat daerah cenderung merupakan senjangan anggaranyang positif, karena menjaga hubungannya dengan kepala daerah dan mengamankan pekerjaan dan posisi atau jabatan di pemerintahan (Mardiasmo, 2001). Jadi partisipasi anggaran yang tinggi dapat menyebabkan terjadinya senjangan anggaran. Hal dapat diartikan bahwa partisipasi pegawai dalam anggaran, akan membuat pegawai leluasa dalam menentukan apa yang akan di capai untuk kepentingannya sendiri bukan kepentingan organisasi atau institusi. Hasil penelitian ini sejalan dengan penelitian terdahulu yang dilakukan oleh Lau dan Eggleton (2003), Veronika dan Komang (2009) , Afiani (2010), Lowe dan Shaw (1968), Merchant (1981), Young (1985), menunjukkan bahwa partisipasi yang tinggi dalam proses penyusunan anggaran, dapat menimbulkansenjangan anggaran (budgetslack) yang tinggi pula.

Berdasarkan hasil analisis pada Tabel 8, hipotesis 2 yang menyatakan bahwa pengaruh interaksi partisipasi anggaran dengan asimetri informasi terhadap senjangan angaran memiliki nilai koefisien jalur sebesar -1,386598 dan T-Stastistics $(1,863918)$ $>$ T-table $(1,65)$ dengan signifikansi level 10\% (two tailed), menunjukkan interaksi antara partisipasi anggaran dengan asimetri informasi terdapat pengaruh negatif signifikan, artinya bahwa asimetri informasi tidak mampu memperkuat hubungan partisipasi ang- garan terhadap senjangan anggaran. Artinya hipotesis 2 ditolak. Hal ini terjadi karena koefisien jalur berlawanan dengan hipotesis yaitu bernilai negatif sebesar -1,386598. Hasil tersebut menunjukkan bahwa interaksi partisipasi anggaran dan asimetri informasi berpengaruh signifikan negatif terhadap senjangan anggaran (budgetary slack), artinya kondisi asimetri informasi yang terjadi antara agen dan prinsipal yang berpartisipasi dalam penganggaran, dapat menurunkan kemungkinan terjadinya senjangan anggaran.

Kondisi asimetri informasi artinya pegawai semakin mengenal secara teknis tentang pekerjaan dan pegawai mempunyai pemahaman lebih baik mengenai apa yang dapat dicapai di area tanggung jawab masing-masing, sehingga secara tidak langsung terjadi penurunan kesenjangan anggaran dikarenakan anggaran sudah tepat sasaran. Tindakan yang diambil pegawai sebagai pihak yang mempunyai kepentingan terhadap perencanaan anggaran, melaporkan kekonsistenan terhadap target kinerja yang diharapkan atau menyatukan hubungan antara masukan (input) dengan keluaran (output) suatu program/kegiatan sesuai dengan kenyataan yang ada sehingga terjadi penurunan kesenjangan anggaran.

Hasil penelitian ini tidak sejalan dengan penelitian terdahulu yang dilakukan oleh Young (1985), Utomo (2006), Djasuli dan Fadilah (2011) menya- 
takan bahwa interaksi partisipasi anggaran dan asimetri informasi berpengaruh positif dan signifikan pada budgetary slack. Namun hasil penelitian ini, sejalan dengan penelitian terdahulu yang dilakukan oleh Falikhatun (2007) yang menyatakan bahwa asimetri informasi tidak mampu memperkuat pengaruh partisipasi anggaran terhadap senjangan. Hal tersebut disebabkan karena peraturan yang jelas mengenai tugas dan kewajiban setiap aparat termasuk aturan yang terkait informasi yang dimiliki oleh bawahan yang harus dilaporkan kepada atasannya maupun kepada dinas instansi terkait anggaran, seperti dinas PPKAD, BAPPEDA dan LITBANG secara berkala, mengenai perkembangan anggaran pendapatan dan belanja daerah (APBD). Jadi, dapat dinyatakan bahwa asimetri informasi dapat memperlemah pengaruh partisipasi anggaran pada senjangan anggaran (budgetary slack) di SKPD Kabupaten Dompu.

Berdasarkan hasil analisis pada Tabel 8, hipotesis 3 yang menyatakan bahwa pengaruh interaksi partisipasi anggaran dengan penekanan anggaran terhadap senjangan angaran memiliki nilai koefisien jalur sebesar -1,442018 dan T-Stastistics $(1,880793)$ $>$ T-table $(1,65)$ dengan signifikansi level 10\% (two tailed), menunjukkan interaksi antara partisipasi anggaran dengan penekanan anggaran terdapat pengaruh negatif signifikan, artinya bahwa penekanan anggaran tidak mampu memperkuat hubungan partisipasi anggaran terhadap senjangan anggaran. Artinya hipotesis 3 ditolak. Hal ini terjadi karena koefisien jalur berlawanan dengan hipotesis yaitu bernilai negatif sebesar $-1,442018$.

Hasil tersebut menunjukkan bahwa interaksi partisipasi anggaran dan penekanan anggaran berpengaruh negative signifikan pada senjangan anggaran, artinya penekanan anggaran yang dilakukan atasan (principal) yang berpartisipasi dalam penganggaran, mampu menurunkan kemungkinan terjadinya senjangan anggaran yakni ketika atasan mempunyai informasi yang lebih baik dibandingkan bawaahan, pengawasan terhadap penyusunan anggaran akan lebih baik, sehingga menghindari bawahan melakukan senjangan anggaran. Hasil penelitian ini, tidak sejalan dengan penelitian terdahulu yang dilakukan oleh oleh Afiani (2010), Chalos dan Poon (2000), Setiadi et al. (2013), Triana et al. (2012) dan Purgianto (2009) yang menunjukkan hasil signifikan antara pengaruh budget emphasis terhadap slack anggaran. Namun, penelitian ini sejalan dengan penelitian yang dilakukan Dunk (1993) menemukan bahwa penekanan anggaran yang tinggi maka senjangan anggaran rendah.

Penjelasan di atas, tentunya akan sesuai dengan konsep keagenan, penekanan anggaran berpengaruh terhadap slack anggaran karena adanya pengukuran kinerja agen, berbasis anggaran dalam suatu organisasi. Falikhatun (2008) menyatakan bahwa bawahan menciptakan slack anggaran dipengaruhi oleh keinginan dan kepentingan agen sehingga akan memudahkan pencapaian target anggaran, terutama jika penilaian prestasi agen ditentukan berdasarkan pencapaian anggaran. Keberhasilan dalam pelaksanaan anggaran akan menunjukkan kinerja yang bagus. Peran atasan dalam melakukan pengawasan karena memiliki informasi yang lebih dan memastikan anggarannya berada dalam tingkat yang relevan untuk dicapai, sehingga bawahan yang mencoba memperoleh penghasilan yang lebih, promosi, naik jabatan, atau penghargaan lainnya dengan cara menciptakan senjangan anggaran akan dapat dihindari. Jadi, dapat dinyatakan bahwa penekanan anggaran dapat memperlemah pengaruh partisipasi anggaran pada senjangan anggaran di SKPD Kabupaten Dompu.

Berdasarkan hasil analisis pada Tabel 8, hipotesis 4 yang menyatakan bahwa pengaruh interaksi partisipasi anggaran dengan komitmen organisasional terhadap senjangan angaran memiliki nilai T-Statistics $(1,660693)>$ T-table $(1,65)$ dengan signifikansi level $10 \%$ (two tailed), menunjukkan bahwa terdapat pengaruh signifikan yakni komitmen organisasional memoderasi hubungan partisipasi anggaran terhadap senjangan anggaran. Artinya hipotesis 4 diterima. Komitmen organisasional mempengaruhi motivasi individu untuk melakukan suatu hal (Yulianti, 2014). Partisipasi anggaran dapat merusak motivasi bawahan dan menurunkan usaha pencapaian tujuan organisasi jika terdapat kecacatan dalam goal setting (Muhammad,2001). Hal ini disebabkan oleh beberapa faktor yaitu siapa yang seharusnya dilibatkan dalam penyusunan anggaran dan keputusan-keputusan apa saja yang memerlukan partisipasi. Kelemahan yang lain yaitu dapat menciptakan partisipasi semu yaitu agent seakan-akan berpartisipasi tapi kenyataannya tidak, agent biasanya hanya dikumpulkan dan diminta menandatangani anggaran yang telah disusun. Sehingga walaupun komitmen organisasional tinggi, belum mampu menurunkan senjangan anggaran, dikarenakan menurunnya motivasi dan semangat kerja serta agen seakan-akan berpartisipasi tapi kenyatannya tidak. Hasil penelitian ini sejalan dengan penelitian terdahulu yang dilakukan oleh Ikhsan dan Ane (2007) menyatakan bahwa komitmen organisasional mampu memoderasi pengaruh anggaran partisipatif pada budgetary slack. Jadi, dapat dinyatakan bahwa komitmen organisasional dapat memperkuat pengaruh partisipasi anggaran pada senjangan anggaran (budgetary slack) di SKPD Kabupaten Dompu. 


\section{SIMPULAN}

Berdasarkan pengujian yang dilakukan dengan SmartPLS 2.0 dapat disimpulkan bahwa dari hasil pengujian peneliti menemukan bukti adanya pengaruh signifikan antara partisipasi anggaran terhadap senjangan anggaran. Hal ini menunjukkan bahwa partisipasi anggaran pada Pemerintah Daerah Kabupaten Dompu yang tinggi dapat meningkatkan senjangan anggaran. Kemudian masih terdapat faktor lain yang mempengaruhi senjangan anggaran (slack budgeting) pada Pemerintah Daerah Kabupaten Dompu. Hasil pengujian terhadap asimetri informasi dan penekanan anggaran menemukan bukti pengaruh negatif signifikan terhadap senjangan anggaran, hal ini menunjukkan bahwa asimetri informasi dan penekanan anggaran dapat menurunkan senjangan anggaran sehingga asimetri informasi dan penekanan anggaran bukan merupakan variabel pemoderesi, sedangkan hasil pengujian komitmen organisasional menemukan bukti pengaruh signifikan meterhadap senjangan anggaran, hal ini menunjukkan bahwa komitmen organisasional dapat meningkatkan senjangan anggaran, sehingga komitmen organisasional merupakan variabel pemoderasi.

Secara praktis, hasil penelitian ini dapat memberikan implikasi bahwa dalam proses penyusunan anggaran partisipasif di pemerintah daerah dan pimpinan organisasi SKPD, perlu untuk dipertimbangan faktor-faktor yang mempengaruhi partisipasi penganggaran yang dapat berdampak pada senjangan anggaran, yaitu: asimetri informasi, penekanan anggaran dan komitmen organisasional. Secara teoritis, hasil penelitian ini memberikan penjelasan bahwa partisipasi anggaran yang tinggi di pemerintah daerah justru meningkatkan senjangan anggaran.

Dalam penelitian ini, ditemukan terdapat variabel-variabel yang bersifat situasional yang mempengaruhi hubungan partisipasi anggaran terhadap senjangan anggaran diantaranya asimetri informasi yakni adanya perbedaan informasi antara agen (bawahan) dan prinsipal (atasan), penekanan anggaran yakni anggaran dijadikan tolak ukur kinerja dan komitmen organisasional, yakni komitmen individuindividu dalam organisasi. Ketiga variabel tersebut dalam penelitian ini berpengaruh signifikan terhadap hubungan partisipasi anggaran terhadap senjangan anggaran. Hasil ini semakin memperkuat konsep dari teori kontinjensi sebagaimana yang dipaparkan di bagian sebelumnya.

Beberapa saran yang dapat dilakukan dalam penelitian mendatang adalah Penelitian selanjutnya hendaknya memperluas obyek penelitiannya, tidak terbatas pada satu Kabupaten saja melainkan lebih dari pada satu kabupaten/kota atau lingkup penelitian pada satu Provinsi, agar dapat melakukan perbandingan antara Kabupaten satu dengan yang lainnya. Penelitian selanjutnya dapat mengembangkan model penelitian dengan menambahkan faktor-faktor lain yang dapat mempengaruhi partisipasi penganggaran dan kinerja aparat. Variabel lain yang dapat disarankan untuk dimasukkan ke penelitian selanjutnya adalah variabel ketepatan anggaran, ketidakpastian lingkungan, dan kapasitas individu.

\section{DAFTAR PUSTAKA}

Afiani, D. N. 2010. Pengaruh Partisipasi Anggaran dan Asimetri Informasi Terhadap Sejangan Anggaran Pada Pemerintah Daerah. Skripsi, Universitas Diponogoro.

Arifin W., B. 2012. Pengaruh Partisipasi Anggaran, Kejelasan Sasaran Anggaran, Pengendalian Akuntansi dan Sistem Pelaporan terhadap Akuntabilitas Kinerja Instansi Pemerintah Daerah dengan Komitmen organisasional Sebagai Variabel Pemoderasi. Jurnal Akuntansi dan Investasi, 13 (1), 15-27.

Begum, A. 2009. Pengaruh Penganggaran Partisipatif Terhadap Kesenjangan Anggaran Dengan Budaya Organisasi Sebagai Variabel Pemoderasi. Tesis, Universitas Indonesia.

Brahmayanti dan Sholihin. 2006. Pengaruh Keputusan Hubungan Antara Asimetri Informasi Dengan Senjangan Anggaran dibawah Metode Kompensasi Truth Inducing. Journal of Indonesian Economy Business, 21 (2).

Brownell, P. 1982. The Role of Accounting Data in Performance Evaluation, Budgetary Partisipative, and Organizational Effectiveness. Journal of Accounting Research, 12-27.

Chalos, P. dan M. C. Poon. 2000. Participation and Performance in Capital Budgeting Teams. Behavioral Research in Accounting, 12, 199.

Coryanata, I. 2006. Partisipasi Anggaran dan Orientasi Tujuan Sistem Organisasi sebagai Variabel Moderating dalam Hubungan antara Orientasi Profesional dan Konflik Peran pada Rumah Sakit Di Prop. Bengkulu. Jurnal Akuntansi dan Investasi, 7 (2), 268-287.

Darlis, E. 2002. Analisis Pengaruh Komitmen organisasionalonal dan Ketidakpastian Lingkungan terhadap Hubungan antara Partisipasi Anggaran dengan Senjangan Anggaran. Jurnal Riset dan Akuntansi Indonesia, 5 (1).

Davis, K., dan J. W. Newstrom. 1985. Human Behavior at Work. Organizational Behavior 
Seventh Edition. Buku Terjemahan Mc. Graw Hill, inc. Edisi 7. Jilid 1. Surabaya: Erlangga.

Desmiyati. 2009. Pengaruh Partisipasi Penganggaran terhadap Senjangan Anggaran dengan Komitmen organisasional sebagai Variabel Moderating. Jurnal Pekbis, 1 (2), 91-99.

Djasuli, M., dan N. I. Fadilah. 2011. Efek Interaksi Informasi Asimetri, Budaya Organisasi, Group Cohesiveness dan Motivasi dalam Hubungan Kausal antara Budgeting Participation dan Budgetary slack. ISSN: 1858-2559. Proceeding PESAT (Psikologi, Ekonomi, Sastra, Arsitektur dan Sipil) Vol. 4.

Dunk, A. S. 1993. The Effect of Budget Emphasis and Information Asymmetry on the Relation Between Budgetary Participation and slack. The Accounting Review, 68,400-410.

Falikhatun. 2007. Interaksi Informasi Asimetri, Budaya Organisasi dan Group Cohesiveness dalam Hubungan Antara Partisipasi Penganggaran dan Budgetarys Sack. Paper dipresentasikan pada Simposium Nasional Akuntansi X, Makassar.

Fitri, Y. 2004. Pengaruh Informasi Asimetri, Partisipasi Penganggaran, dan Komitmen Organisasi Terhadap Timbulnya Senjangan Anggaran. Paper dipresentasikan pada Simposium Nasional Akuntansi VII, Denpasar.

Fitriatsuri. 2005. Pengaruh Partisipasi Anggaran Terhadap Senjangan Anggaran dengan Variabel Moderat Komitmen Organisasional, Desentralisasi dan Ketidakpastian Lingkungan pada Pemerintah Kota Palembang. Tesis. Universitas Bina Darma.

Gamal, M. 2001. Pengaruh Interaksi Partisipasi Anggaran, Informasi Asimetris dan Penekanan Anggaran Terhadap Budgetslack (Studi Kasus pada Samudra Indonesia Group). Tesis, Universitas Diponegoro.

Ghozali, I., dan H. Latan. 2012. Partial Least Square Konsep, Teknik dan Aplikasi Smart PLS 2.0. Semerang: M3.BP-Universitas Diponegoro.

Ghozali, I. 2008. Structural Equation Modeling Alternatif dengan Partial Least Square (PLS). Semerang: M3.BP-Universitas Diponegoro.

Govindarajan, V. 1986. Impact of Participation in The Budgetary Process on Managerial Attitudes and Performance: Universaliticand Contingency Perspective. Decision Sciences, 17, 496-516.

Govindarajan, V. dan R. N. Anthony. 2007. Management Control Systems. Twelfth Edition. McGraw-Hill International Edition.

Hasanah dan Suartana. 2014. Pengaruh Interaksi Motivasi Dan Budaya Organisasi Pada
Hubungan Antara Partisipasi Penyusunan Anggaran dengan Senjangan Anggaran. EJurnal Akuntansi Universitas Udayana.

Ikhsan, A. dan L. Ane. 2007. Pengaruh Partisipasi Anggaran terhadap Senjangan Anggaran dengan Menggunakan Lima Variabel Pemoderasi. Paper dipresentasikan pada Simposium Nasional Akuntansi X, Makassar.

Jogiyanto. 2011. Konsep dan Aplikasi Structural Equation Modelling Berbasis Varian dalam Penelitian Bisnis. Yogyakarta: UPP STIM YPKN.

Kartiwa, H. A. 2004. Proses Penyusunan Anggaran (APBD) dan Arah Kebijakan Umum .Makalah. Sukabumi, 8 Desember 2004.

Luthan, F. 1998. Organisasi Behavior, Eighth Edition. New York: McGraw-Hill, International Book Company.

Mahmudi, 2003. New Public Management (NPM); Pendekatan Baru Manajemen Sektor Publik. Sinergi. Kajian Bisnis dan Manajemen, 6 (1), 69-79

Minan, K. 2005. Pengaruh Komitmen organisasional terhadap Hubungan antara Partisipasi Penganggaran dengan Senjangan Anggaran pada Perguruan Tinggi Swasta di Kota Medan. Tesis, Universitas Sumatera Utara.

Novita, D., I. Sam dan S. Jumaili. 2009. Analisis Pengaruh Partisipasi Penganggaran, Informasi Asimetri, Komitmen organisasional Terhadap 78 Budgetary Slack di PDAM Tirta Mayang Kota Jambi. Jurnal Cakrawala Akuntansi, 1 (1), $1-10$.

Purgianto. E. 2009. Analisis Pengaruh Strategi Institusi, Tekanan Anggaran dan Conflict of Interest Terhadap Senjangan Anggaran. Jurnal Akuntansi Universitas Muhamadiyah Yogyakarta, 5.

Purwantini, C., dan I. B. Suratno. 2007. Perbedaan Partisipasi Anggaran Ditinjau dari Jenis Jabatan, Tingkat Pendidikan, Jenis Kelamin dan Pengalaman Kerja (Studi Empirik pada Perguruan Tinggi Swasta di Daerah Istimewa Yogyakarta). Jurnal Akuntansi dan Investasi, 8 (1), 33-45.

Rani, A. 2015. Kemampuan Asimetri Informasi, Ketidakpastian Lingkungan, Budget Emphasis, Dan Kapasitas Individu Sebagai Variabel Moderasi Terhadap Partisipasi Anggaran Pada Budgetary Slack (Studi Kasus Pada SKPD Di Kabupaten Badung). Tesis, Universitas Udayana.

Robbin, S. P. dan Judge.2008. Prilaku Organisasi . Jakarta : Salemba Empat 
Suartana, I. W. 2010. Akuntansi Keperilakuan Teori dan Implementasi. Yogyakarta: C.V Andi Offset.

Sofyani, H. dan R. Akbar. 2013. Hubungan Faktor Internal Institusi dan Implementasi Sistem Akuntabilitas Kinerja Instansi Pemerintah (SAKIP) di Pemerintah Daerah. Jurnal Akuntansi dan Keuangan Indonesia, 10 (2), 184205.

Sofyani, H. dan R. Akbar. 2015. Hubungan Karakteristik Pegawai Pemerintah Daerah Dan Implementasi Sistem Pengukuran Kinerja: Perspektif Ismorfisma Institusional. Jurnal Akuntansi \& Auditing Indonesia, 19 (2), 153173.

Sopiah, 2008. Perilaku Organisasi, Andi, Yogyakarta

Sujana, I. K., 2010. Pengaruh Partisipasi Penganggaran, Penekanan Anggaran, Komitmen organisasional, Asimetri Informasi, dan Ketidakpastian Lingkungan terhadap Budgetary slack. Jurnal Ilmiah Akuntansi dan Bisnis, 5 (2).

Sumarno, J. 2005. Pengaruh Komitmen organisasional dan Gaya Kepemimpinan terhadap Hubungan antara Partisipasi Anggaran dan Kinerja Manajerial. Jurnal Bisnis Strategi, 14 (2).

Supanto 2010. Analisis Pengaruh Partisipasi Penganggaran Terhadap Budgetaryslack Dengan Informasi Asimetri, Motivasi, Budava Organisasi Sebagai Pemoderasi (Studi Kasus Pada Politeknik Negeri Semarang). Tesis, Universitas Diponegoro.

Supriyatno. 2010. Pengaruh Partisipasi Pejabat Struktural dalam Penyusunan Anggaran, Komitmen organisasional, Profesionalisme dan Struktur Organisasi pada Kinerja Manajerial Pemerintah Kota Denpasar. Tesis, Universitas Udayana.

Syam dan Djalil, 2006. Pengaruh Orientasi Profesional Terhadap Konflik Peran : Interaksi Antara Partisipasi Anggaran dan Pengunaan Anggaran Sebagai Alat Ukur Kinerja Dengan Orientasi Manajerial (Suatu Penelitian Empiris pada Perguruan Tinggi Negeri dan Swasta di Provinsi Nanggroe Aceh Darussalam), Simposium Nasional Akuntansi IX, Padang

Utomo. 2006. Administrasi Publik Baru Indonesia. Yogyakarta: Pustaka Pelajar

Veronika, A. dan K. A. Krisnadewi. 2008. Pengaruh Partisipasi Penganggaran, Tekanan anggaran, Komitmen organisasional, dan Kompleksitas Tugas Terhadapslack Anggaran Pada BPR di
Kabupaten Badung. Jurnal Akuntansi Fakultas Ekonomi Udayana. 